\title{
Herd Management Factors That Affect Duration and Variation of Adherence of an External Teat Sealant
}

\author{
G. H. Lim, ${ }^{*}$ D. F. Kelton, ${ }^{\star}$ K. E. Leslie, ${ }^{\star}$ L. L. Timms,† C. Church, $\neq$ and R. T. Dingwell ${ }^{\star 1}$ \\ *Department of Population Medicine, Ontario Veterinary College, Guelph, Ontario, N1G 2W1 Canada \\ †Department of Animal Science, lowa State University, Ames 50011-3150 \\ $\ddagger$ Tavistock Veterinarians, Tavistock, Ontario, NOB 2R0 Canada
}

\section{ABSTRACT}

During 1998 and 1999, a purposive sample of Ontario dairy herds was enrolled in a study to examine management factors associated with adherence of an external teat sealant. A total of 74 herds were recruited that had previously complied with a provincial Sentinel Herd mastitis study. All herds were sent a management survey and a commercially available external teat sealant product. The sealant was applied to all cows in first lactation or greater that were scheduled to go dry. Adherence of the teat sealant was scored on a scale of 1 to 5 ( 1 = sealant completely removed) for the first $12 \mathrm{~d}$ following dry off. Complete data were analyzed from 806 cows in 48 herds (mean of 17 cows/ herd). Mean duration of adherence of the teat sealant was $4 \mathrm{~d}$ (range 1 to $7 \mathrm{~d}$ ). Of the management factors recorded, only changing the feed to reduce milk production prior to drying off was significantly associated with $0.78-d$ prolonged adherence. No factors related to dry cow housing, bedding material, or floor surface were associated with the duration of adherence. The variance around the duration of adherence was examined. The median variance of adherence was $3.0 \mathrm{~d}^{2}$, which was equivalent to a standard deviation of 2.6 d. Herds in which dry cows were housed in tie-stall barns, and the herds that used a penicillin and novobiocin combination dry cow antibiotic had the greatest variation. We concluded that modifying the ration to reduce milk production enhanced adherence of an external teat sealant. Teat-end preparation prior to application of the teat sealant is an important factor to consider when choosing to adopt this dry period mastitis prevention strategy. This study demonstrates that beyond cow- and quarter-level factors, herd management factors can influence the duration and variation of sealant adherence experienced among different herds.

Received August 11, 2006.

Accepted October 5, 2006.

${ }^{1}$ Corresponding author: dingwell@uoguelph.ca
Key words: teat sealant, dry period, adherence, herd management

\section{INTRODUCTION}

The mammary gland is susceptible to new infections during the dry period, particularly at drying off and near parturition (Bradley and Green, 2000; Dingwell et al., 2003). Physiological changes in the mammary gland and teat canal have been implicated as reasons for this increased risk. Milk leakage is strongly associated with the probability of infection (Waage et al., 1998; Waage et al., 2001).

The teat canal is an important defense mechanism of individual quarters (Day, 1990; Capuco et al., 1992). The formation of the teat canal keratin plug decreases susceptibility to infection (Williamson et al., 1995; Dingwell et al., 2004). Moreover, the time required for this plug to form is quite variable and can take upward of $7 \mathrm{~d}$ to achieve. Therefore, methods aimed at protecting the teat end may reduce the susceptibility to new infection.

One approach is to use an internal teat sealer. An inert viscous paste is administered into the teat canal at drying off, filling the crevices of the teat canal and lower teat sinus cavity. A tight seal is formed, and pathogens are prevented from entering the teat canal. The teat sealer resides in the teat canal for the duration of the dry period and is removed at calving by manual stripping (Woolford et al., 1998). The effectiveness of this product has been widely investigated (Godden et al., 2003; Cook et al., 2005; Sanford et al., 2006) and all studies have reported beneficial results. This may be because the sealer remains in the teat end for the entire dry period.

Another alternative to protecting the teat end at the beginning of the dry period is to use an external dry cow teat sealant, or barrier teat dip. Nevertheless, there is evidence to suggest that the ability of the product to reduce the level of infection at calving is related to the duration of adherence at drying off (Timms, 2001). Researchers have suggested that the lack of prolonged adherence could be the reason bene- 
ficial results were absent in their studies (McArthur et al., 1984; Matthews et al., 1988). In one study, none of the sealants lasted more than $24 \mathrm{~h}$ (Matthews et al., 1988).

Several factors were identified as influencing the duration of sealant adherence, such as the season of application, teat characteristics, and formulation type (Lim et al., 2000). Still, these results vary among herds, suggesting that herd-level factors influence the duration of sealant adherence to the teat end. Herd management practices were identified as being important when evaluating susceptibility to infection, and relationships were identified between the type of management practices adopted and the prevalence of infection within the herd (Barkema et al., 1998).

The objective of this study was to identify specific dry cow management procedures that would enhance the duration and reduce the variation in adherence of an external dry cow teat sealant to the teat end in selected commercial dairy herds in Ontario.

\section{MATERIALS AND METHODS}

\section{Herd and Cow Enrollment}

This study was conducted from January 1998 to April 1999. A purposive sample of 74 Ontario dairy producers was selected to participate based on their interest in the study and their compliance with the study protocol and data recording. A portion of the producers selected were participants in the Ontario Sentinel Herd project, which was initiated to identify the current status and trends in udder health in the province (Kelton et al., 1998). In the Sentinel project, health management veterinarians identified a list of producers from which the participants were selected. For the current dry cow teat sealant project, these same veterinarians identified additional producers that had the interest in participating and the compliance to participate. Each participating producer was instructed to enroll all cows entering the dry period. The current lactation, drying off, and dry period management practices used on the farm were not altered.

\section{Treatment Protocol}

All herds were provided with the sealant product and applicator cups. After completing their routine drying off procedures, producers were instructed to clean all teats and teat ends using a cotton swab soaked in alcohol. Then, using the applicator cup, producers were instructed to dip all teats of all cows in a commercially available dry cow teat sealant formulation, DryFlex (DeLaval, Kansas City, MO). For $1 \mathrm{~d}$ following application, producers were instructed to ob-
Score Adherence

5
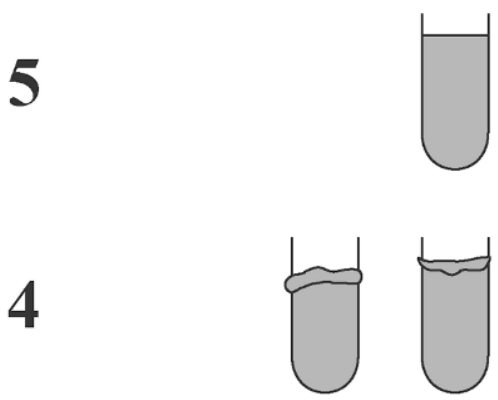

3
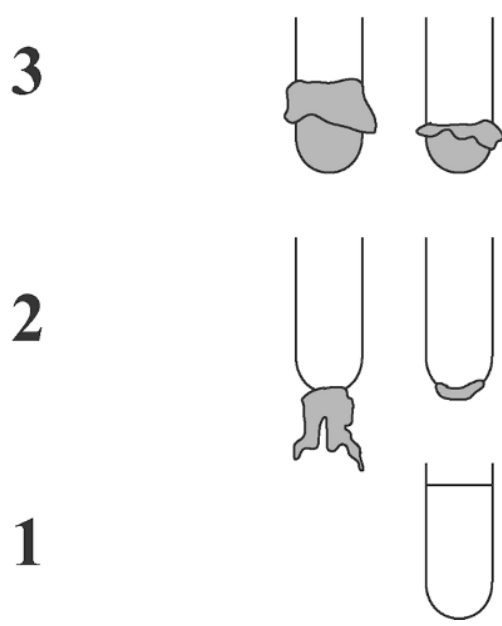

Figure 1. Illustration of the scoring system used to evaluate adherence of external teat sealant applied at drying off.

serve the adherence of the sealant on the teat end for up to $12 \mathrm{~d}$. Adherence was scored on a scale of 1 to 5 , with a score of 5 corresponding to a tightly covered teat, with very little or no signs of wear, whereas a score of 1 corresponded to the sealant being completely removed. If the sealant was almost completely off but the teat end was still covered, this was a score of 2 . Light and early signs of removal to moderate or significant wear corresponded to scores of 4 and 3, respectively (Figure 1).

\section{Recorded Variables}

Producers were mailed a herd survey and individual data sheets for each cow. The survey was used to determine the type of management procedures that were practiced on each farm. The dry-off date and expected calving date were also recorded. All data were returned by mail at the conclusion of the trial. 


\section{Data Calculations}

The duration of sealant adherence was determined to be $0 \mathrm{~d}$ if the sealant was absent from the teat end on the first day of observation. Instances in which the sealant remained on the teat end on the last day of observation were assigned a maximum value of $12 \mathrm{~d}$. Teat-level observations of adherence were summarized for each herd to determine the impact of herd management procedures. Therefore, outcomes of interest in this investigation were the average herd adherence (days) and the total herd variation in adherence $\left(\right.$ days $\left.^{2}\right)$.

Analyzed variables were dry cow management factors, which included the type of dry cow housing (stalls or loose housing), the surface of dry cow housing, bedding used in dry cow housing (straw, shavings, manure pack), the effect of letting dry cows out to pasture during the summer, altering feed rations prior to drying off (decreasing concentrate ratio), the method of milk cessation (abrupt vs. intermittent), the type of dry cow intramammary antibiotic used, and the method of administering dry cow antibiotics (full vs. partial insertion).

\section{Descriptive and Statistical Analyses}

All data were entered using Microsoft Excel (Microsoft, Redmond, WA) and verified through duplicate data entry. Subsequent descriptive and statistical analyses were conducted in SAS version 8.0 (SAS Institute, Cary, NC). All statistical tests were based on the natural log-transformed values $\left(\log _{\mathrm{e}}\right)$ of the herd mean in adherence and the herd variation in adherence. Descriptive analyses and univariate tests were first conducted to identify general trends in the data. Least squares regression in the univariate and multivariate analyses were carried out using the MIXED procedure in SAS. Variables included in the final model were significant at the $5 \%$ level. Model fit was assessed using the Akaike information criterion, as well as through an examination of the residuals to ensure that model assumptions were met.

\section{RESULTS}

\section{Herd Profiles}

Of the 74 herds initially enrolled in this trial, individual data record sheets and herd surveys were collected from 48 producers. Complete data for 806 cows were available for analysis. The average number of cows that were enrolled on each farm was $16.5 \pm 2.1$ (range 3 to 56 cows).
A summary of responses to selected survey questions is presented in Table 1. In most herds (70.8\%), dry cows were always housed in a separate area from lactating cows. Bedded packs and tie-stall barns were the most frequent type of dry cow housing used (39.6 and 37.5\%, respectively), and slightly more than half of the producers indicated that they did not use rubber mattresses as a stall surface for the dry cow housing facilities. Straw was the most frequently used bedding material (83.0\%). More than two-thirds of the producers indicated that dry cows were let out to pasture during the summer (68.1\%). Most producers reported changing the feeding regimen prior to drying off. By far, reducing feed was the most common practice $(51.6 \%)$. Although no producer indicated restricting water intake alone, 2 reported adopting that strategy in addition to reducing the feed prior to drying off. Slightly more than half of the producers reported drying off cows using the abrupt method of milk cessation (56.2\%), as opposed to gradual intermittent cessation of milking. Nearly all producers reported using blanket dry cow therapy (91.7\%). Only 4 of 48 producers used a selective approach to intramammary antibiotic treatment of cows at drying off, relying primarily on the individual cow SCC data for decision making.

Although producers were instructed to enroll cows entering the dry period, there were indications that some producers enrolled cows that were approaching parturition. A total of 74 cows from 8 herds were excluded for this reason, leaving 732 cows (46 herds) available for analysis. Meaningful variables from Table 1 were assessed in the subsequent analyses. The impact of letting dry cows out to pasture during the summer on the mean duration of sealant adherence in each herd could not be assessed because of the meager number of observations. Only 4 herds out of 48 had submitted data in which more than half of the cows were dried off during the summer.

\section{Herd Average in Sealant Adherence}

A frequency distribution of the average herd adherence values observed across the 46 farms is shown in Figure 2. The median average herd adherence was $4.4 \mathrm{~d}$ (range 1.5 to $7.2 \mathrm{~d}$ ). Summary statistics for the average herd adherence observed across levels for each of the analyzed variables are presented in Table 2 . None of the management factors that were related to dry cow housing, including the type of housing, floor surface, and bedding material, was significantly associated with the average herd adherence. With respect to practices aimed at reducing the milk production level at drying off, only changing the feed prior to drying off was associated with increasing the duration 
Table 1. Herd management survey responses from 48 dairy herds, 1997 to 1999

\begin{tabular}{|c|c|c|}
\hline Item & Herds, \% & Herds, $\mathrm{n}$ \\
\hline \multicolumn{3}{|c|}{ Dry cows are housed separately from lactating cows } \\
\hline Always & 70.8 & 34 \\
\hline No & 29.2 & 14 \\
\hline \multicolumn{3}{|l|}{ Type of dry cow housing } \\
\hline Bedded pack & 39.6 & 19 \\
\hline Free-stall barn & 22.9 & 11 \\
\hline Tie-stall barn & 37.5 & 18 \\
\hline \multicolumn{3}{|c|}{ Mattress lines floor surface of housing } \\
\hline Yes & 42.9 & 18 \\
\hline No & 57.1 & 24 \\
\hline \multicolumn{3}{|c|}{ Material used in bedding contains straw } \\
\hline Yes & 83.0 & 39 \\
\hline No & 17.0 & 8 \\
\hline \multicolumn{3}{|c|}{ Let out to pasture during summer } \\
\hline Yes & 68.1 & 32 \\
\hline No & 31.9 & 15 \\
\hline \multicolumn{3}{|c|}{ Change feeding prior to drying off } \\
\hline Yes & 64.6 & 31 \\
\hline Reduce feed only & 51.6 & 16 \\
\hline Change or remove feed only & 25.8 & 8 \\
\hline Restrict water intake only & 0.0 & 0 \\
\hline Combination & 22.6 & 7 \\
\hline No & 35.4 & 17 \\
\hline \multicolumn{3}{|l|}{ Method of drying off } \\
\hline Gradual & 43.8 & 21 \\
\hline Abrupt & 56.2 & 27 \\
\hline \multicolumn{3}{|c|}{ Dry cow antibiotic used on all cows } \\
\hline Yes & 91.7 & 44 \\
\hline No & 8.3 & 4 \\
\hline \multicolumn{3}{|l|}{ Dry cow antibiotic used } \\
\hline Cephapirin & 45.8 & 22 \\
\hline Cloxacillin & 25.0 & 12 \\
\hline Penicillin + novobiocin & 29.2 & 14 \\
\hline \multicolumn{3}{|l|}{ Dry cow tube infusion method } \\
\hline Partial & 85.4 & 41 \\
\hline Full & 14.6 & 7 \\
\hline
\end{tabular}

of sealant adherence at drying off $(P=0.05)$. The method of drying off was not associated with the average herd adherence. The type of dry cow antibiotic did not have a significant impact on the average herd adherence.

In the multivariate modeling, no significant interactions were identified among any of the analyzed variables. In addition, with changing feeding practices in the model, none of the other herd management practices were statistically associated with the log-transformed values of the average herd adherence. Herds that implemented dietary changes prior to drying off cows achieved a $0.20 \pm 0.10$ increase in the log-transformed values of average herd adherence $(P=0.05)$. Equivalently, the average herd adherence was $0.78 \mathrm{~d}$ higher in herds that implemented feeding changes prior to drying off than in herds that did not (4.38 vs. $3.60 \mathrm{~d}$, respectively).

\section{Herd Variance in Sealant Adherence}

A herd-level variance estimate was determined for each farm as a measure of the total variation in dura- tion of sealant adherence values observed in each farm. A frequency distribution of these values is shown in Figure 3. The median herd variance was $3.0 \mathrm{~d}^{2}($ range 0.3 to $16.8 \mathrm{~d}^{2}$ ). Summarized over all teat-level observations, the variation in duration of sealant adherence was $6.8 \mathrm{~d}^{2}$. Equivalently, the standard deviation was $2.6 \mathrm{~d}$. Summary statistics for herd-level variance are provided in Table 3 . The same variables that were investigated for the average days of adherence were investigated for this outcome. The type of dry cow housing facility was significantly associated with the herd variation in adherence. Free-stall and tie-stall barns were associated with the greatest variation in adherence, whereas herds that housed dry cows in a bedded pack facility experienced the lowest variation in sealant adherence. Herds that used a rubber mattress stall surface for dry cow housing facilities were associated with a higher level of variation in adherence. Variance estimates among levels of the remaining management practices were similar, and none was statistically significant.

In the final multivariate model, only the type of dry cow housing facility as well as the type of dry cow 


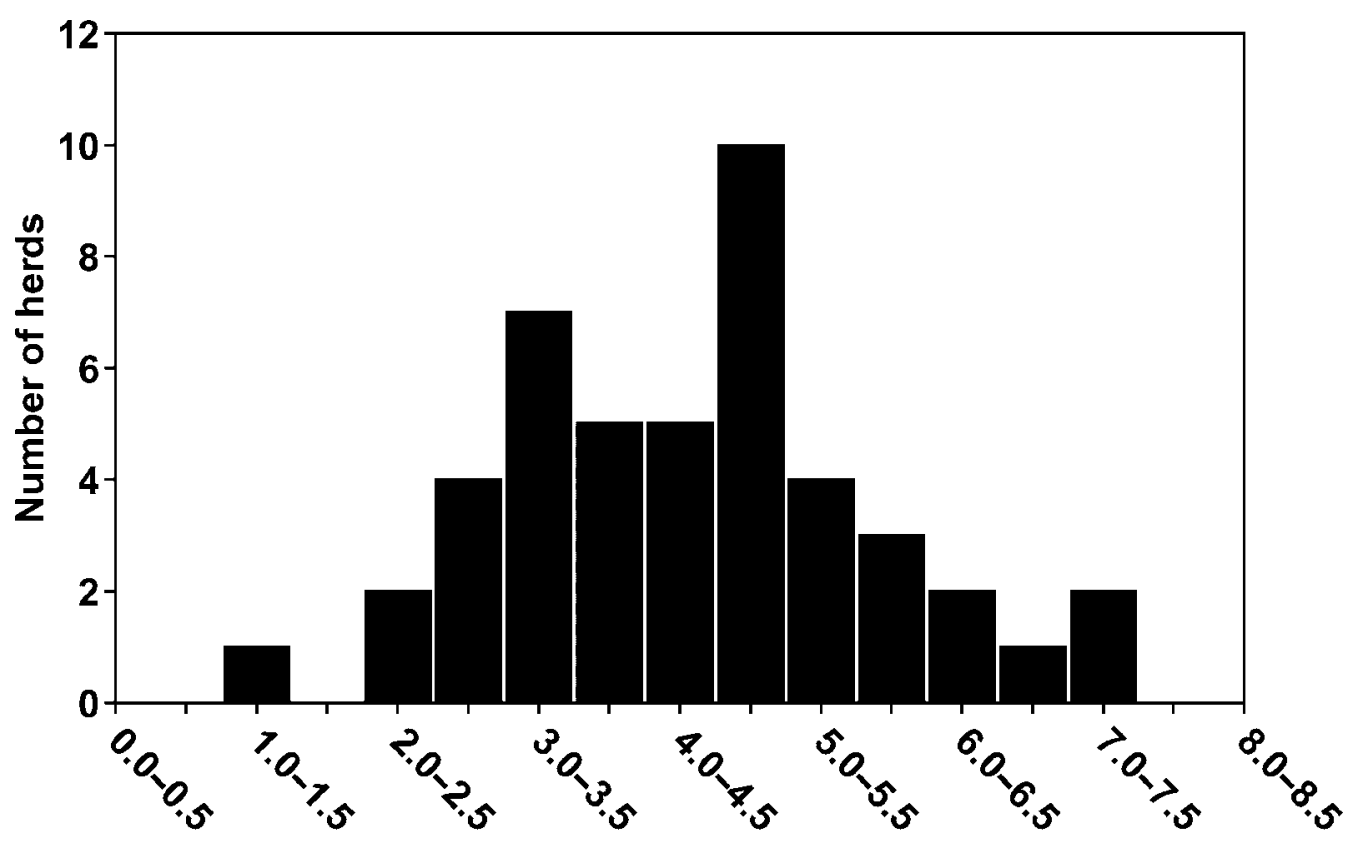

Herd mean duration of sealant adherence, $d$

Figure 2. Distribution of herd-level mean duration of external teat sealant observed.

antibiotic product used were significantly associated with the total variation in duration of sealant adherence observed on each farm (Table 4). The herd varia- tion observed for farms that housed dry cows in tiestall barns was associated with the greatest variation, and was higher compared with farms that housed dry

Table 2. Herd-level mean days of adherence of an external teat sealant by analyzed variables

\begin{tabular}{|c|c|c|c|c|}
\hline Item & Mean $^{1,2}$ & $\mathrm{SE}^{1}$ & Herds, n & $P^{2}$ \\
\hline Type of dry cow housing & & & & 0.30 \\
\hline Bedded pack & 4.0 & 0.3 & 19 & \\
\hline Free-stall barn & 4.5 & 0.4 & 9 & \\
\hline Tie-stall barn & 4.5 & 0.3 & 18 & \\
\hline Mattress lines floor surface of housing & & & & 0.42 \\
\hline Yes & 4.5 & 0.3 & 17 & \\
\hline No & 4.2 & 0.3 & 23 & \\
\hline Material used in bedding contains straw & & & & 0.85 \\
\hline Yes & 4.2 & 0.5 & 8 & \\
\hline No & 4.4 & 0.2 & 37 & \\
\hline Change feeding prior to drying off & & & & 0.05 \\
\hline No & $3.7^{\mathrm{a}}$ & 0.3 & 15 & \\
\hline Yes & $4.6^{\mathrm{b}}$ & 0.2 & 31 & \\
\hline Method of drying off & & & & 0.61 \\
\hline Gradual & 4.4 & 0.3 & 20 & \\
\hline Abrupt & 4.3 & 0.3 & 26 & \\
\hline Dry cow antibiotic used & & & & 0.81 \\
\hline Cephapirin & 4.1 & 0.2 & 20 & \\
\hline Cloxacillin & 4.3 & 0.4 & 12 & \\
\hline Penicillin + novobiocin & 4.6 & 0.4 & 14 & \\
\hline Dry cow tube infusion method & & & & 0.74 \\
\hline Full & 4.6 & 0.7 & 7 & \\
\hline Partial & 4.3 & 0.2 & 39 & \\
\hline
\end{tabular}

${ }^{\mathrm{a}, \mathrm{b}}$ Row means with different superscripts are different $(P<0.05)$.

${ }^{1}$ Summary statistics shown are for the average herd adherence (in days).

${ }^{2}$ Statistical tests are based on the log-transformed $\left(\log _{\mathrm{e}}\right)$ average herd adherence. 


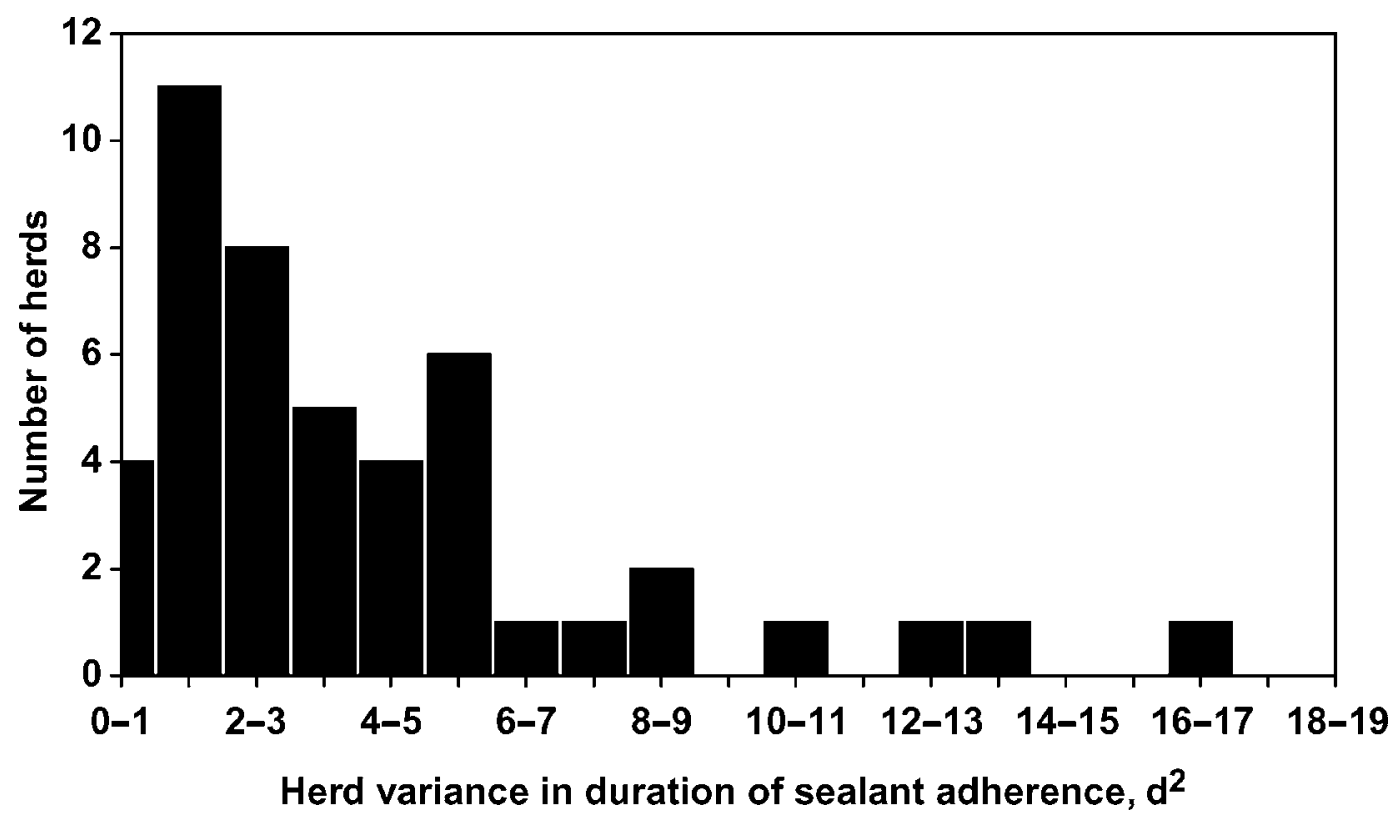

Figure 3. Distribution of herd-level variation of duration of external teat sealant adherence observed.

cows in a bedded pack $(P<0.05)$. But the variation observed in herds that used free-stall barns was not different from any of the other types of housing facilities. Herds that used cephapirin bezathine (CefaDri; Wyeth Animal Health, Guelph, Ontario, Canada) were associated with the least amount of variation, whereas herds that used a penicillin and novobiocin product (NovaDry; Pfizer Animal Health, Montreal, Quebec, Canada) were associated with the greatest variation $(P=0.02)$.

Table 3. Herd-level variation in duration of adherence by analyzed variables $\left(\right.$ days $\left.^{2}\right)$

\begin{tabular}{|c|c|c|c|c|}
\hline Item & Mean $^{1,2}$ & $\mathrm{SE}^{1}$ & Herds, n & $P^{2}$ \\
\hline Type of dry cow housing & & & & 0.02 \\
\hline Bedded pack & $2.4^{\mathrm{a}}$ & 0.3 & 19 & \\
\hline Free-stall barn & $5.2^{\mathrm{ab}}$ & 1.6 & 9 & \\
\hline Tie-stall barn & $5.3^{\mathrm{b}}$ & 0.9 & 18 & \\
\hline Mattress lines floor surface of housing & & & & 0.02 \\
\hline Yes & $6.1^{\mathrm{a}}$ & 1.2 & 17 & \\
\hline No & $3.1^{\mathrm{b}}$ & 0.4 & 23 & \\
\hline Material used in bedding contains straw & & & & 0.83 \\
\hline Yes & 4.4 & 1.8 & 8 & \\
\hline No & 3.9 & 0.5 & 37 & \\
\hline Change feeding prior to drying off & & & & 0.55 \\
\hline No & 4.2 & 1.2 & 15 & \\
\hline Yes & 4.1 & 0.5 & 31 & \\
\hline Method of drying off & & & & 0.58 \\
\hline Gradual & 3.7 & 0.6 & 20 & \\
\hline Abrupt & 4.4 & 0.8 & 26 & \\
\hline Dry cow antibiotic used & & & & 0.17 \\
\hline Cephapirin & 3.0 & 0.5 & 20 & \\
\hline Cloxacillin & 4.7 & 1.2 & 12 & \\
\hline Penicillin + novobiocin & 5.2 & 1.2 & 14 & \\
\hline Dry cow tube infusion method & & & & 0.77 \\
\hline Full & 4.1 & 2.1 & 7 & \\
\hline Partial & 4.1 & 0.5 & 39 & \\
\hline
\end{tabular}

${ }^{\mathrm{a}, \mathrm{b}}$ Row means with different superscripts are different $(P<0.05)$.

${ }^{1}$ Summary statistics shown are for the average herd adherence (in days).

${ }^{2}$ Statistical tests are based on the log-transformed $\left(\log _{\mathrm{e}}\right)$ average herd adherence. 
Table 4. Final model parameter estimates for the log-transformed $\left(\log _{\mathrm{e}}\right)$ values of herd variation in adherence $\left(\right.$ days $\left.^{2}\right)$

\begin{tabular}{|c|c|c|c|c|c|c|}
\hline \multirow[b]{2}{*}{ Variable } & \multicolumn{3}{|c|}{ Parameter } & \multicolumn{3}{|c|}{ Least squares mean } \\
\hline & Estimate & $\mathrm{SE}$ & $P$ & $\begin{array}{c}\log _{e} \\
\text { herd } \\
\text { variance }\end{array}$ & $\begin{array}{c}\text { Herd } \\
\text { variance, } \\
\mathrm{d}^{2}\end{array}$ & $\begin{array}{c}\text { Herd } \\
\text { SD, } \\
\text { d } \\
\end{array}$ \\
\hline Type of dry cow housing & & & $<0.01$ & & & \\
\hline Bedded pack & -0.93 & 0.26 & & $0.63^{\mathrm{a}}$ & 1.88 & 1.37 \\
\hline Free-stall barn & -0.29 & 0.32 & & $1.27^{\mathrm{ab}}$ & 3.58 & 1.89 \\
\hline Tie-stall barn & & & & $1.57^{\mathrm{b}}$ & 4.78 & 2.19 \\
\hline Dry cow antibiotic used & & & 0.02 & & & \\
\hline Cephapirin & -0.79 & 0.28 & & $0.77^{\mathrm{a}}$ & 2.15 & 1.47 \\
\hline Cloxacillin & -0.42 & 0.31 & & $1.14^{\mathrm{ab}}$ & 3.14 & 1.77 \\
\hline Penicillin + novobiocin & & & & $1.56^{\mathrm{b}}$ & 4.76 & 2.18 \\
\hline
\end{tabular}

${ }^{\mathrm{a}, \mathrm{b}}$ Row means with different superscripts are different $(P<0.05)$.

\section{DISCUSSION}

The herds making up the study population were purposively selected. Although a range of herd management types were investigated, the profile of producers in this survey was similar to that in another survey conducted among all Ontario dairy producers (Dimmick, 2001). Producers were selected for their perceived compliance and willingness to participate in this study. Therefore, they may not necessarily be representative of the entire Ontario dairy industry, and the results from this study may only be inferred for these selected herds.

The overall mean average herd adherence was 4.40 $\pm 0.05 \mathrm{~d}(2,906$ teats). This value exceeds what was reported in previous studies using lactating cow barrier teat dips during the dry period (McArthur et al., 1984; Matthews et al., 1988). The current teat sealant product used (DryFlex) was a revised version of the previous formulation (Stronghold). The manufacturer modified the original formulation to achieve superior adherence in the newer formulation. In previous unpublished research, the mean days of duration achieved by dipping teats once at drying off was 2.60 $\pm 0.16 \mathrm{~d}$ (213 teats), which suggests that indeed the newer formulation (DryFlex) demonstrated superior adherence. Yet additional factors, such as when the sealant was applied after drying off and the season of application, were also important considerations. The season in which cows were enrolled was highly variable among herds in this study.

The primary objective of this investigation was to identify herd management factors that would enhance the duration of sealant adherence to the teat end or that contributed to the variation in sealant adherence observed on a farm. Therefore, 2 outcomes were derived to reflect these objectives: the average herd adherence and the herd variance in adherence.
In the analysis to identify factors that enhanced the mean duration of sealant adherence to the teat end, only modifying the diet prior to drying off was statistically significant. We hypothesize that this was related to the level of milk production level at drying off, which was not available for this analysis. Also, the presence or absence of milk leaking from teats was not recorded, which might be used as a surrogate explanatory measure of the effect seen from changing the diet. But dry cow teat sealants do not prevent teats from leaking milk (Hemling et al., 1998). Therefore, management factors that would decrease the probability of milk leaking would likely enhance teat-end adherence.

Milk production was related to the time to teat closure, and we hypothesized that leaking teats were caused by the increased intramammary pressure resulting from a full mammary gland (Oliver and Sordillo, 1989; Dingwell et al., 2004). Because teat closure and milk leakage are associated with the susceptibility to new IMI (Waage et al., 2001; Dingwell et al., 2004), researchers should reinvestigate methods to reduce the milk production level at drying off (Dingwell et al., 2001).

Very limited and dated research has shown that in the absence of dry cow therapy, gradual milk cessation is associated with a decrease in the susceptibility to new IMI (Natzke et al., 1975). Nonetheless, because almost all of the producers in this study reported using dry cow therapy on all cows, this would account for the lack of association between the method of drying off and the average herd adherence. Beneficial results were gained by gradually drying cows off only when it was accompanied with a change in the feed ration prior to drying off (Bushe and Oliver, 1987). This suggests that nutrition practices are more important for reducing milk production than the method of drying off. Furthermore, this concept supports the finding that only changing the feed ration prior to drying off 
significantly enhanced the average herd adherence value.

In the second multivariate analysis, the type of housing facility and the type of dry cow antibiotic used contributed to the herd variation in adherence. Dry cows that were housed in tie-stall barns were associated with the greatest variation, whereas those that were housed in bedded packs were associated with the smallest variation. This could be related to the comfort level of the cow in its environment, which has been studied (Anderson, 2001). The design of tie-stall and free-stall housing facilities can interfere with the natural movement of the cow, particularly in lying down and getting up. In contrast, cows that are housed in bedded packs can rise up and lie down smoothly, unencumbered by any restraints. Under this scenario, it would seem less likely for the udder to be placed in an awkward position, where the sealant might be rubbed off the teat when the cow is rising. Therefore, the increased variation in sealant adherence observed in herds with dry cows housed in tie-stall and freestall barns could be a reflection of the variation in movement between cows. No specific explanation for the influence of type of dry cow therapy product on herd variation in adherence is readily available. Other than capturing the specific product used among farms by method of survey, no emphasis was placed on comparing or investigating differences among products. One plausible hypothesis is that a difference existed in the carrier between products. Both Cefa-Dri and Dry-Clox have a peanut oil carrier, which Novodry does not have, and this might have influenced the variation in adherence if the product and carrier remained on the teat end. Further research would be necessary to explain this finding.

\section{CONCLUSIONS}

The results indicate that altering the feed ration prior to drying off enhanced the duration of sealant adherence to the teat end. Data on neither milk production nor on milk leaking from the teats were recorded, so we can only hypothesize that this effect is attributable to changes in milk production. The types of dry cow housing facility and dry cow antibiotic used were associated with the variation in adherence observed in these surveyed herds, and may be an indication of the increased variability introduced among cows under these scenarios. This study demonstrates that in addition to teat-level and cow-level factors, herd management practices significantly influence the duration of sealant adherence on the teat end. Therefore, these management factors should be taken into account when attempting to identify herds that would achieve the most beneficial result from the use of an external teat sealant for the prevention of IMI in dry cows.

\section{REFERENCES}

Anderson, N. 2001. Time-lapse video opens our eyes to cow behaviour and comfort. Pages 35-42 in 34th Annu. Proc. Am. Assoc. Bovine Pract., Rome, GA. Am. Assoc. Bovine Pract., Auburn, AL.

Barkema, H. W., Y. H. Schukken, T. J. Lam, M. L. Beiboer, G. Benedictus, and A. Brand. 1998. Management practices associated with low, medium, and high somatic cell counts in bulk milk. J. Dairy Sci. 81:1917-1927.

Bradley, A. J., and M. J. Green. 2000. A study of the incidence and significance of intramammary enterobacterial infections acquired during the dry period. J. Dairy Sci. 83:1957-1965.

Bushe, T., and S. P. Oliver. 1987. Natural protective factors in bovine mammary secretions following different methods of milk cessation. J. Dairy Sci. 70:696-704.

Capuco, A. V., S. A. Bright, J. W. Pankey, D. L. Wood, R. H. Miller, and J. Bitman. 1992. Increased susceptibility to intramammary infection following removal of teat canal keratin. J. Dairy Sci. 75:2126-2130.

Cook, N. B., D. A. Pionek, and P. Sharp. 2005. An assessment of the benefits of Orbeseal ${ }^{\circledR}$ when used in combination with dry cow antibiotic therapy in three commercial dairy herds. The Bovine Practitioner 39:83-94.

Day, T. 1990. New udder infections during the dry period. Dairy Cattle Soc. Newslett. 7:7-9.

Dimmick, B. 2001. Portrait of an industry. Pages 30-36 in Ontario Milk Producer. Dairy Farmers of Ontario, Mississauga, Canada.

Dingwell, R. T., D. F. Kelton, K. E. Leslie, and V. L. Edge. 2001. Deciding to dry off: Does level of production matter. Pages $69-$ 79 in Natl. Mastitis Counc. Annu. Mtg. Proc., Fort Worth, TX. National Mastitis Council Inc., Madison, WI.

Dingwell, R. T., K. E. Leslie, and D. F. Kelton. 2003. Management of the dry cow in control of peripartum disease and mastitis. Vet. Clin. North Am.: Food Anim. Pract. 19:157-169.

Dingwell, R. T., K. E. Leslie, Y. H. Schukken, J. M. Sargeant, L. L. Timms, T. F. Duffield, G. P. Keefe, D. F. Kelton, K. D. Lissemore, and J. Conklin. 2004. Association of cow and quarter-level factors at drying off with new intramammary infections during the dry period. Prev. Vet. Med. 63:75-89.

Godden, S., P. Rapnicki, S. Stewart, J. Fetrow, A. Johnson, R. Bey, and R. Farnsworth. 2003. Effectiveness of internal teat seal in the prevention of new intramammary infections during the dry and early-lactation periods in dairy cows when used with a dry cow intramammary antibiotic. J. Dairy Sci. 86:3899-3911.

Hemling, T. C., M. Henderson, A. Britten, and N. Hanson. 1998. Effect of teat prep procedures on adherence of a dry cow teat sealant. Pages 265-266 in Natl. Mastitis Counc. Annu. Mtg. Proc. National Mastitis Council Inc., Madison, WI.

Kelton, D. F., M. A. Godkin, D. Alves, K. Lissemore, K. E. Leslie, B. McEwen, and C. Church. 1998. Sentinel herds to monitor udder health and milk quality in the province of Ontario. Pages $238-240$ in 37th Natl. Mastitis Counc. Annu. Mtg. Proc. National Mastitis Council Inc., Madison, WI.

Lim, G. H., K. E. Leslie, J. Morgan, B. Dow, D. Kelton, T. F. Duffield, and J. TenHag. 2000. An evaluation of factors affecting the efficacy of a dry cow teat seal. Pages 245-246 in Natl. Mastitis Counc. Annu. Mtg Proc., Atlanta, GA. National Mastitis Council Inc., Madison, WI.

Matthews, K. R., R. J. Harmon, B. E. Langlois, W. L. Crist, and R. W. Hemken. 1988. Use of latex teat dip with germicide during the prepartum period. J. Dairy Sci. 71:1940-1946.

McArthur, B. J., T. P. Fairchild, and J. J. Moore. 1984. Efficacy of a latex teat sealer. J. Dairy Sci. 67:1331-1335.

Natzke, R. P., R. W. Everett, and D. R. Bray. 1975. Effect of drying off practices on mastitis infection. J. Dairy Sci. 58:1828-1835. 
Oliver, S. P., and L. M. Sordillo. 1989. Approaches to the manipulation of mammary involution. J. Dairy Sci. 72:1647-1664.

Sanford, C. J., G. P. Keefe, I. R. Dohoo, K. E. Leslie, R. T. Dingwell, L. DesCoteaux, and H. W. Barkema. 2006. Efficacy of using an internal teat sealer to prevent new intramammary infections in non-lactating dairy cattle. J. Am. Vet. Med. Assoc. 228:15651573.

Timms, L. 2001. Field trial evaluations of a novel persistent barrier teat dip for preventing mastitis during the dry period and as a potential substitute for dry cow antibiotic therapy. Pages 262263 in Natl. Mastitis Counc. Annu. Mtg. Proc., Reno, NV. National Mastitis Council Inc., Madison, WI.
Waage, S., S. A. Odegaard, A. Lund, S. Brattgjerd, and T. Rothe. 2001. Case-control study of risk factors for clinical mastitis in postpartum dairy heifers. J. Dairy Sci. 84:392-399.

Waage, S., S. Sviland, and S. A. Odegaard. 1998. Identification of risk factors for clinical mastitis in dairy heifers. J. Dairy Sci. $81: 1275-1284$.

Williamson, J. H., M. W. Woolford, and A. M. Day. 1995. The prophylactic effect of a dry-cow antibiotic against Streptococcus uberis. N. Z. Vet. J. 43:228-234.

Woolford, M. W., J. H. Williamson, A. M. Day, and P. J. A. Copeman. 1998. The prophylactic effect of a teat sealer on bovine mastitis during the dry period and the following lactation. N. Z. Vet. J. 46:12-19. 